\title{
P-glycoprotein and breast cancer resistance protein in acute myeloid leukaemia cells treated with the Aurora-B Kinase Inhibitor barasertib- hQPA
}

Martin Grundy ${ }^{1,2^{*}}$, Claire Seedhouse ${ }^{1}$, Nigel H Russell ${ }^{1,3}$ and Monica Pallis ${ }^{2}$

\begin{abstract}
Background: Aurora kinases play an essential role in orchestrating chromosome alignment, segregation and cytokinesis during mitotic progression, with both aurora-A and B frequently over-expressed in a variety of human malignancies. Over-expression of the ABC drug transporter proteins P-glycoprotein (Pgp) and Breast cancer resistance protein (BCRP) is a major obstacle for chemotherapy in many tumour types with Pgp conferring particularly poor prognosis in acute myeloid leukaemia (AML). Barasertib-hQPA is a highly selective inhibitor of aurora-B kinase that has shown tumouricidal activity against a range tumour cell lines including those of leukaemic AML origin.
\end{abstract}

Methods: Effect of barasertib-hQPA on the pHH3 biomarker and cell viability was measured in a panel of leukaemic cell lines and 37 primary AML samples by flow cytometry. Pgp status was determined by flow cytometry and BCRP status by flow cytometry and real-time PCR.

Results: In this study we report the creation of the cell line OCI-AML3DNR, which over-expresses Pgp but not BCRP or multidrug resistance-associated protein (MRP), through prolonged treatment of OCI-AML3 cells with daunorubicin. We demonstrate that Pgp (OCI-AML3DNR and KG-1a) and BCRP (OCI-AML6.2) expressing AML cell lines are less sensitive to barasertib-hQPA induced pHH3 inhibition and subsequent loss of viability compared to transporter negative cell lines. We also show that barasertib-hQPA resistance in these cell lines can be reversed using known Pgp and BCRP inhibitors. We report that barasertib-hQPA is not an inhibitor of Pgp or BCRP, but by using ${ }^{14}[C]$-barasertib-hQPA that it is effluxed by these transporters. Using phosphoHistone $\mathrm{H3}(\mathrm{pHH})$ as a biomarker of barasertib-hQPA responsiveness in primary AML blasts we determined that Pgp and BCRP positive primary samples were less sensitive to barasertib-hQPA induced pHH3 inhibition $(p=<0.001)$ than samples without these transporters. However, we demonstrate that $I C_{50}$ inhibition of pHH3 by barasertib-hQPA was achieved in $94.6 \%$ of these samples after 1 hour drug treatment, in contrast to the resistance of the cell lines.

Conclusion: We conclude that Pgp and BCRP status and $\mathrm{pHH}$ down-regulation in patients treated with barasertib should be monitored in order to establish whether transporter-mediated efflux is sufficient to adversely impact on the efficacy of the agent.

\footnotetext{
* Correspondence: martin.grundy@nottingham.ac.uk

'Department of Academic Haematology, The University of Nottingham,

Clinical Sciences Building, Hucknall Road, Nottingham, NG5 1PB, UK

Full list of author information is available at the end of the article
} 


\section{Background}

The mammalian aurora kinases aurora- $\mathrm{A}$, aurora-B and aurora-C comprise a family of serine/threonine kinases that are essential for cell cycle control and mitotic progression [1]. Interest in the auroras has intensified since the observation that both aurora-A and B are overexpressed in a wide variety of tumour types [2-5] including those of leukaemic origin [6,7]. The implication of the auroras in tumourigenesis and the fact that that they are kinases, amenable to small molecule inhibition, makes them attractive targets for anticancer drug development. Success of agents such as imatinib in the treatment of chronic myelogenous leukaemia has increased confidence that small-molecule inhibitors of specific kinases may prove to be highly effective anticancer agents [8]. Despite having high sequence homologies in their kinase domains the three aurora members have very distinct subcellular localizations and functions during mitosis [9]. Aurora-B is a chromosomal passenger protein which undergoes dynamic localization during mitosis, associating first to the inner centromeric region during prometaphase, and then to the spindle midzone and midbody during late anaphase and telophase suggesting a role in cytokinesis $[1,10]$. Aurora- $\mathrm{B}$ is the catalytic component of the chromosomal passenger complex (CPC), which is composed of three additional non-catalytic subunits that direct its activity: survivin, inner centromere protein (INCENP) and borealin. The CPC orchestrates the spindle checkpoint and ensures the accurate segregation of chromatids and correct microtubule/kinetochore attachment during mitosis and cytokinesis [11]. Aurora-B is also known to phosphorylate Histone $\mathrm{H} 3(\mathrm{pHH} 3)$ at the serine 10 position during mitosis $[12,13]$. Inhibition of Histone H3 phosphorylation has been reported to prevent initiation of chromosome condensation and entry into mitosis [14]. Aurora$\mathrm{A}$ is known to phosphorylate numerous centrosomal proteins and primarily functions in centrosomal regulation and mitotic spindle formation with loss of AuroraA function leading to cell cycle arrest and monopolar mitotic spindles [9]. Aurora- $C$ is the least studied of the aurora family and is highly expressed in the testis where it is thought to have a specific role in the regulation of chromosome segregation during male meiosis [15]. More recently aurora-c has been identified at low levels in sixteen other tissues including bone marrow with studies suggesting that it has a complementary role to aurora B and Survivin as a chromosomal passenger protein $[16,17]$.

A growing number of aurora kinase inhibitors have been described that show anti-tumour activity in vivo. Three non-selective aurora kinase inhibitors ZM447439, Hesperadin and VX-680 all induce similar phenotypes when tested in cell based assays [18-20]. Specifically, all three inhibit phosphorylation of Histone $\mathrm{H} 3$ on serine 10 and induce DNA endoreduplication in the absence of cytokinesis, results that suggest that their cellular effects are largely due to the inhibition of aurora-B [21]. We have previously reported the same cellular phenotype in AML cell lines treated with barasertib-hQPA [22].

Barasertib (formerly AZD1152) is a quinazoline prodrug which is converted in plasma to the more active moiety barasertib-hQPA (AZD1152-hQPA) and it is the more active barasertib-hQPA that has been supplied by AstraZeneca for the purpose of this study. BarasertibhQPA is an aurora kinase inhibitor that has potent selectivity for inhibition of aurora-B (Ki: aurora-B $=0.36$ $\mathrm{nM})$ compared to aurora- $\mathrm{A}$ and $\mathrm{C}\left(\mathrm{K}_{\mathrm{i}}\right.$ : aurora- $\mathrm{A}=1369$ $\mathrm{nM}$ and aurora- $\mathrm{C}=17.0 \mathrm{nM}$ ) and a panel of 50 other kinases [23]. We have however recently reported that the FMS-like tyrosine kinase 3 internal tandem duplication (FLT3-ITD) mutation is a secondary target for barasertib-hQPA in AML cells [22]. Barasertib has been shown to significantly inhibit the growth of human colon, lung and haematological tumour xenografts in immunodeficient mice and as such has been selected for clinical evaluation $[23,24]$. It has also shown tumouricidal activity against a panel of tumour cell lines including those of acute myeloid leukaemia (AML) origin [22,25-27]. Results of a Phase 1 study in AML were reported at ASH 2010 (Abstract 656) and a Phase II study is ongoing.

AML is a heterogeneous clonal disorder of haemopoietic progenitor cells where both failure to differentiate and over proliferation results in accumulation of non-functional cells termed myeloblasts [28]. Intrinsic resistance or treatment-induced acquired resistance is one of the major obstacles to the effective treatment of patients with AML. While nearly $80 \%$ of younger AML patients may initially achieve complete remission with current therapy most will relapse with resistant disease [29]. Clinical outcomes in the elderly have been even more modest as these patients do not tend to tolerate intensive chemotherapy regimens and frequently have poor cytogenetics [30]. Less than $10 \%$ of older patients with AML will achieve long-term disease free survival with conventional chemotherapy [31]. This inability to successfully treat AML patients, particularly the elderly, underlies the continuing need to develop new treatments for AML.

The development of multidrug resistance (MDR) is frequently observed in the treatment of cancer, and is a phenomenon that allows tumour cells that have been exposed to one cytotoxic agent to develop cross resistance to a range of structurally and functionally unrelated compounds. In patients with AML, MDR can be present intrinsically at diagnosis or can arise during chemotherapy as well as at relapse. ATP binding cassette 
$(A B C)$ transporter-mediated active efflux of cytotoxic agents is the most well characterized mechanism by which cancer cells develop MDR, particularly after repeated cycles of chemotherapy [32]. The ABC transporters are an evolutionary extremely well conserved family of transmembrane proteins expressed in most cells and involved in the ATP driven transport of a huge variety of substrates including sugars, peptides, inorganic ions, amino acids, proteins, vitamins and metallic ions [33]. The family currently consists of 49 members, 13 of which are associated with chemotherapeutical drug transport and drug resistance [34]. The genes can be divided into subfamilies based on similarity in gene structure resulting in seven mammalian $\mathrm{ABC}$ gene subfamilies (ABCA, B C, D, E F and G family). The most widely studied members ABCB1 (MDR1/P-glycoprotein), $\mathrm{ABCC} 1$ (multidrug resistance protein, MRP1) and ABCG2 (breast cancer resistance protein, BCRP) have the ability to export a wide variety of structurally unrelated chemotherapeutic compounds from cancer cells, thereby conferring MDR to these cell [33].

Despite improvements accomplished in the last thirty years with the use of combination of cytarabine and intercalating agents, the overall prognosis of adult AML remains poor. One of the best characterized resistance mechanisms in AML is drug extrusion mediated by P-glycoprotein (Pgp). Expression of the MDR1 gene coding for Pgp is high in elderly patients with AML and is associated with worse complete remission rates [30]. Multidrug resistance-associated protein 1 (MRP1) has also been shown to contribute to MDR in AML [30], whereas other studies have been unable to detect any correlation between MRP1 protein expression and clinical response in AML patients [35]. Breast cancer resistance protein (BCRP) has been shown to be overexpressed in 33\% of AML patients with normal karyotype and to significantly affect the duration of complete remissions [36]. Another study showed BCRP expression to be a prognostic factor in AML patients treated with daunorubicin and mitoxantrone but not with idarubicin [37]. Conversely, another group found a prognostic value for Pgp and MRP1 but suggested BCRP has a limited function in the drug efflux related resistance in AML [38]. It has recently been reported that the amplification of genes that encode for Pgp and BCRP can confer resistance to barasertib-hQPA in colon and pancreatic carcinoma cell lines [39].

In this study we will investigate the specificity of barasertib-hQPA in AML cell lines and primary samples in relation to their $\mathrm{ABC}$ transporter status.

\section{Results}

\section{Cell line validation}

The OCI-AML3DNR cell line was created as described in the Methods section. The short tandem repeats
(STR) analysis of the OCI-AML3DNR and OCI-AML6.2 cell lines was shown to be identical to the parent OCIAML3 cell line indicating that there were no significant genetic changes.

\section{Pgp and BCRP expressing cell lines are less sensitive to barasertib-hQPA induced pHH3 inhibition and subsequent loss of viability}

The effects of barasertib-hQPA were examined in logarithmically growing OCI-AML3, OCI-AML3DNR, OCIAML6.2, KG-1a and U937 leukaemic cell lines. Functional Pgp was determined using rhodamine 123 (R123) retention and the known Pgp modulator cyclosporine A (CSA) as a positive control modulator [40], with the KG$1 \mathrm{a}(\mathrm{p}=0.002)$ and daunorubicin selected OCIAML3DNR ( $\mathrm{p}=0.039)$ cell lines showing high Pgp functional expression (Figure 1A). Functional BCRP was measured using BODIPY-prazosin (BODIPY) retention and Fumitremorgin $\mathrm{C}$ (FTC) [41] as a modulator with only the stably transfected BCRP OCI-AML6.2 $(\mathrm{p}=0.015)$ cell line showing any functional BCRP activity. High OCIAML3DNR ( $\mathrm{p}=0.003)$ and KG-1a $(\mathrm{p}=0.006)$ Pgp levels were also observed when we measured Pgp protein using the MRK-16 monoclonal antibody (Figure 1B). To verify that MRP expression had not also been elevated in our daunorubicin selected cell line we used a Calcein-AM retention assay with the MRP modulator MK-571 [42] and compared MRP function to the adriamycin selected, MRP positive, HL-60ADR cell line [43] (Figure 1C). No significant increase in MRP function was detected in the OCI-AML3DNR cells $(p=0.358)$ in contrast to that seen in the HL-60ADR cells $(\mathrm{p}=0.004)$ when compared to the parent cell lines. An in house flow cytometry protocol for measuring pHH3 expression was used and has been described in detail previously [22]. The basal range of pHH3 expression in the cell lines was $1.8-4.8 \%$ of total cells. After 24 hours, at concentrations of $0-1000 \mathrm{nM}$ barasertib-hQPA, inhibition of $\mathrm{pHH} 3$ was achieved in both $\mathrm{ABC}$ transporter negative cell lines (Figure 2A(i) and $2 \mathrm{~B}(\mathrm{i}))$. There was significant inhibition of $\mathrm{pHH} 3$ in the U937 ( $\mathrm{p}=0.001)$ and OCI-AML3 $(\mathrm{p}=0.003)$ cells at $30 \mathrm{nM}$ barasertib-hQPA before complete inhibition at $100 \mathrm{nM}$. The ABC transporter positive cell lines were all much more resistant to $\mathrm{pHH} 3$ inhibition at barasertibhQPA concentrations up to $1000 \mathrm{nM}$. The decrease in pHH3 seen at $300 \mathrm{nM}$ and $1000 \mathrm{nM}$ barasertib-hQPA in the OCI-AML6.2 cells was not statistically significant (p $=0.408 / 0.207$ ). Seventy-two hours incubation with barasertib-hQPA caused loss of viability in both transporter negative cell lines with an almost complete loss of viability achieved at $30 \mathrm{nM}$ (Figure $2 \mathrm{~A}(\mathrm{ii})$ and $2 \mathrm{~B}(\mathrm{ii})$ ). Again, the transporter positive cells were much more resistant, with loss of viability seen only at high dose barasertibhQPA. 


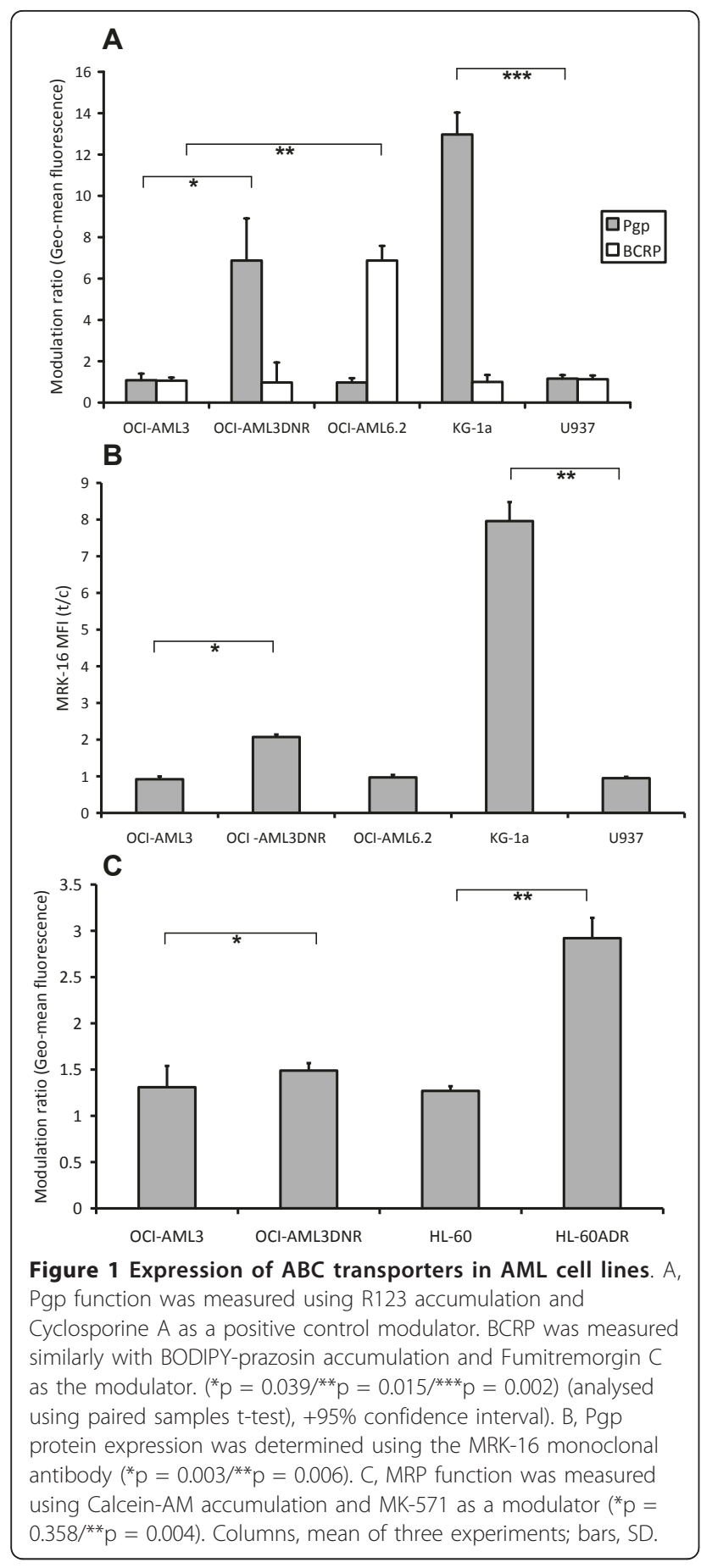

Barasertib-hQPA is not an inhibitor of Pgp or BCRP but it is effluxed by these transporters

To determine whether barasertib-hQPA is able to modulate Pgp or BCRP function we compared it to known modulators using fluorescent dye retention assays. Barasertib-hQPA had no effect on R123 retention in the Pgp positive OCI-AML3DNR cell line (Figure 3A(i)) in contrast to the marked increase in retention seen with CSA
(Figure 3A(ii)). Likewise barasertib-hQPA had no effect on BODIPY retention in the BCRP positive OCIAML6.2 cell line (Figure $3 \mathrm{~B}(\mathrm{i})$ ) in contrast to the increase in retention seen with FTC (Figure 3B(ii)). In these assays barasertib-hQPA did not appear to be a modulator of Pgp or BCRP. We therefore decided to employ the UIC2 shift assay; which is an indirect way of measuring unlabelled Pgp substrates [44]. The reactivity of the UIC2 antibody with Pgp is increased by the addition of Pgp transported compounds. We tested barasertib-hQPA in the UIC2 shift assay using the Pgp positive KG-1a cell line and the known Pgp substrate vinblastine [44] as a positive control (Figure 3C). No shift in UIC2 binding was seen with barasertib-hQPA treatment. Also, co-incubation of barasertib-hQPA and vinblastine, failed to affect any shift seen with vinblastine alone. This assay failed to show that barasertib-hQPA is a Pgp substrate. However it did not prove the converse as a few Pgp substrates such as etoposide fail to alter UIC2 binding depending on their stoichiometry and Pgp ATPase activity [45]. To categorically determine if barasertib-hQPA was being effluxed by Pgp and BCRP we used radiolabelled barasertib-hQPA to measure its cellular retention (Figure 3D). In this assay CSA and FTC increased retention of $\left[{ }^{14} \mathrm{C}\right]$-barasertib-hQPA in both OCIAMLDNR ( $p=0.004)$ and OCI-AML6.2 ( $\mathrm{p}=0.005)$ cells respectively. The modulators increased retention of $\left[{ }^{14} \mathrm{C}\right]$-barasertib-hQPA to at least the concentration seen in the $\mathrm{ABC}$ transporter negative/barasertib-hQPA sensitive OCI-AML3 cell line.

\section{Culture with known inhibitors sensitize Pgp and BCRP positive AML cells to barasertib-hQPA}

Sub-toxic doses of the Pgp inhibitor CSA and also of the BCRP inhibitor FTC were added to cell culture with 10$1000 \mathrm{nM}$ barasertib-hQPA (Figure 4). Addition of CSA sensitizes the Pgp positive cell lines OCI-AML3DNR and KG-1a to pHH3 down-regulation with complete loss of pHH3 seen at 24 hours with $100 \mathrm{nM}$ barasertib-hQPA (Figure $4 \mathrm{~A}(\mathrm{i})$ ). There is no statistical significance in the decrease in $\mathrm{pHH} 3$ at $10 \mathrm{nM}$ barasertib-hQPA plus CSA in the OCI-AML3 cells, or in the increase in pHH3 in KG-1a cells with the same treatment, both $\mathrm{p}=0.145$. The same effect is seen in 72 hour cell viability with a marked decrease in viability at $10 \mathrm{nM}$ and complete loss of cell viability at $100 \mathrm{nM}$ barasertib-hQPA with the addition of CSA (Figure 4A(ii)). The MRP inhibitor MK571 did not sensitize OCI-AML3DNR cells to barasertibhQPA induced pHH3 inhibition, or loss of viability, confirming that resistance is not due to any elevated MRP expression in these cells (Data not shown). Addition of FTC also clearly sensitizes the BCRP positive cell line OCI-AML6.2 to pHH3 down-regulation at barasertib-hQPA concentrations as low as $10 \mathrm{nM}(\mathrm{p}=0.021)$ 


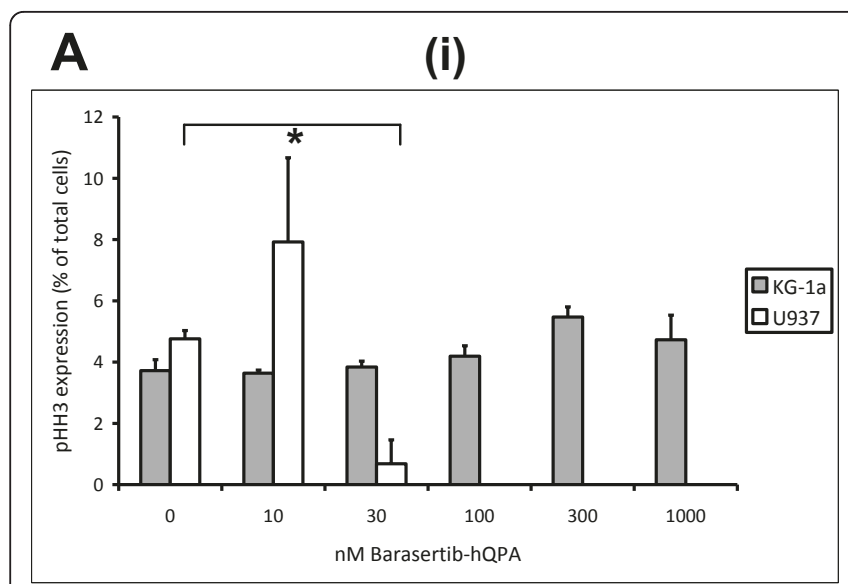

B

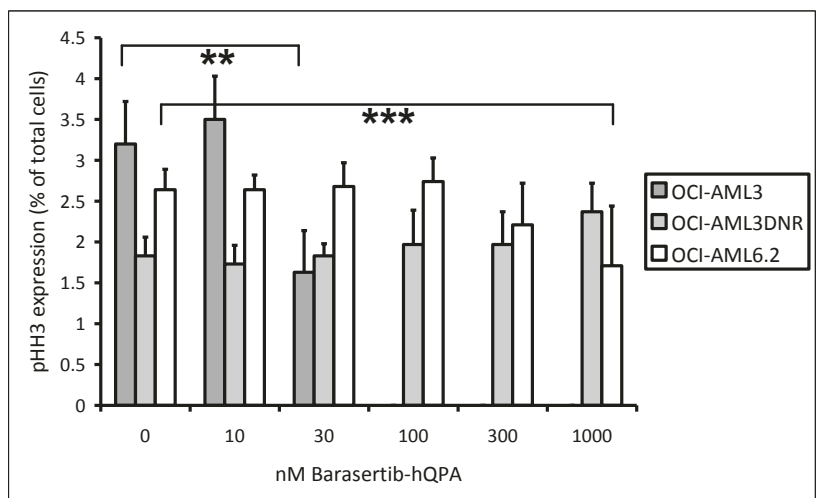

(ii)

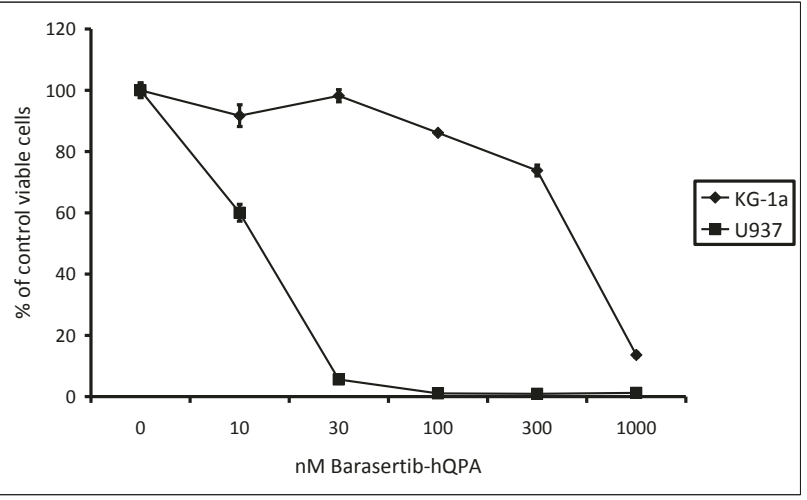

(ii)

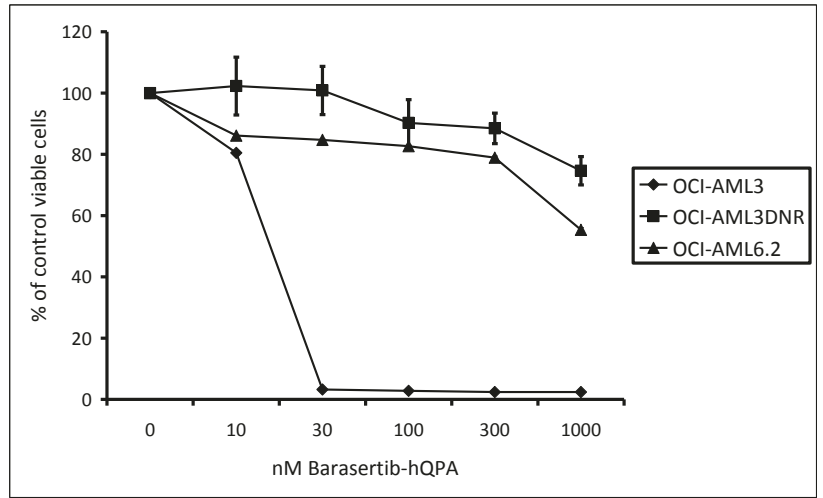

Figure 2 Specificity of barasertib-hQPA in AML cell lines. A(i), B(i) Effect of 24 hours barasertib-hQPA exposure on pHH3 expression in leukaemic cell lines $\left({ }^{*} p=0.001 /{ }^{* *} p=0.003 / * * * p=0.207\right.$ ) (analysed using paired samples t-test), $+95 \%$ confidence interval). A(ii), B(ii) Effect of 72 hours barasertib-hQPA exposure on viable cell count in leukaemic cell lines measured using 7AAD and fixed stained cells. Columns/lines, mean of three experiments; bars, SD.

with complete down-regulation of $\mathrm{pHH} 3$ seen at $100 \mathrm{nM}$ barasertib-hQPA with the addition of FTC (Figure 4B(i)). Complete loss of cell viability at 72 hours was achieved at $100 \mathrm{nM}$ barasertib-hQPA with the addition of FTC (Figure 4B(ii)).

\section{Pgp and BCRP positive primary AML samples are less} sensitive to barasertib-hQPA induced pHH3 inhibition The level of pHH3 detectable in untreated cell lines was low (1.8-4.8\% of total cells) and expression in primary cells was expected to be even lower, as a very small population of cells are actively dividing at the time of sampling. Because of this we pre-incubated primary samples with a cytokine cocktail to drive the cells into cycle before treatment with barasertib-hQPA. Cellular proliferation in primary samples has been confirmed previously using $\left[{ }^{3} \mathrm{H}\right]-\mathrm{Tdr}$ uptake with $\mathrm{pHH} 3$ expression correlating extremely well with the amount of proliferation [22]. Mean basal pHH3 expression in the primary samples was $3.01 \%$ (range, $0.04-13.14 \%$ ) of total cells.
We have previously reported that basal pHH3 expression in our primary samples shows significant correlation with aurora-B mRNA levels $(\mathrm{p}=0.015)$ [22]. $\mathrm{pHH} 3$ expression was measured in 37 primary samples after 1 hr's treatment with $300 \mathrm{nM}$ barasertib-hQPA (Figure $5 \mathrm{~A}) . \mathrm{IC}_{50}$ was achieved in all but 2 samples (94.6\%) with a mean down-regulation of $78 \%$ (Range, 32.7-100\%). Of the primary samples tested $9 / 37$ (24.3\%) were positive for Pgp and 9/35 (25.7\%) positive for BCRP. Mean MRK-16 test/control mean fluorescence intensity (MFI) in the primary samples was 1.13 (range, 0.72-2.92). Mean CSA modulation ratio in the primary samples was 1.74 (range, 0.91-9.16). Five samples co-expressed Pgp and BCRP such that we found a significant correlation ( $\mathrm{p}=0.008$, r2 $=0.238$ ) between Pgp and BCRP expression in our primary samples. The percentage of Pgp and BCRP positive samples and the co-expression correlation agrees with previously published data [36]. Pgp positive samples were significantly ( $p=<0.001$ ) less sensitive to barasertib-hQPA induced pHH3 inhibition than 


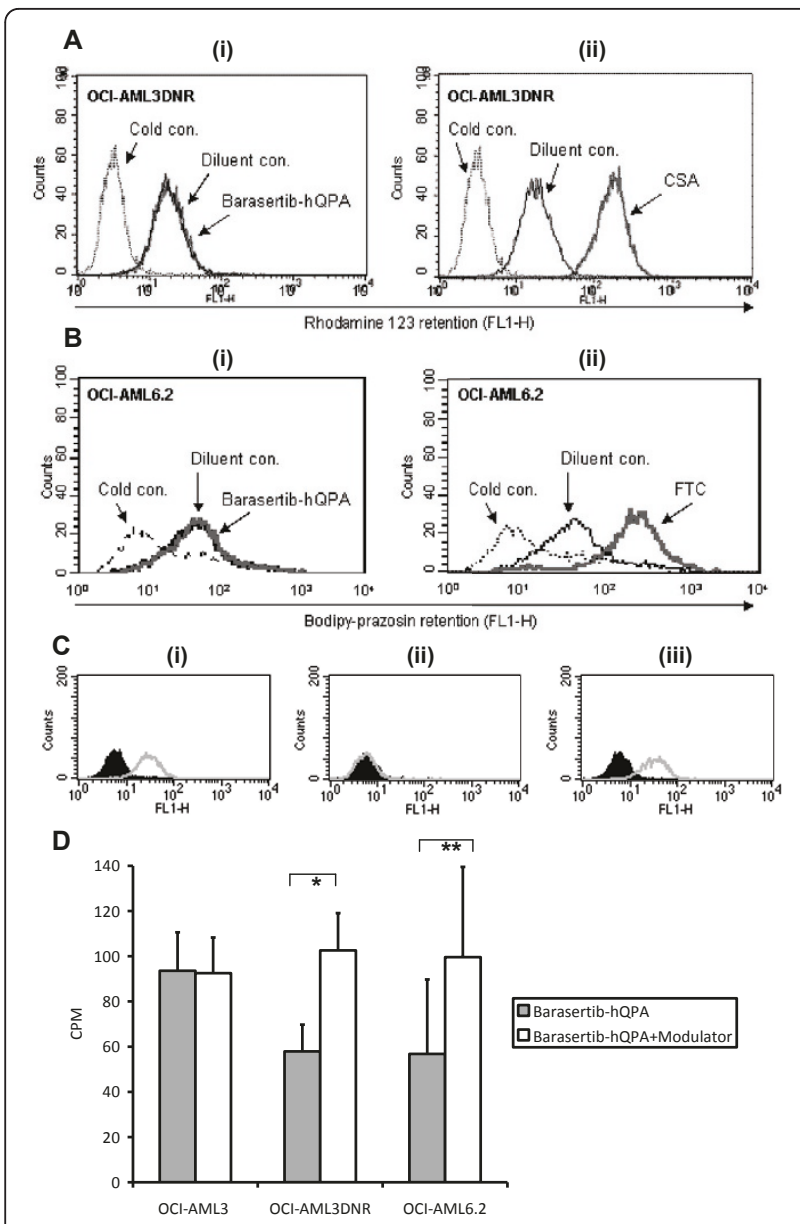

Figure 3 There is no modulation of Pgp or BCRP function by barasertib-hQPA. A, R123 accumulation in OCl-AML3DNR cells +/$300 \mathrm{nM}$ barasertib-hQPA (i) or $2.5 \mathrm{\mu g} / \mathrm{ml}$ CSA (ii). The dotted lines are the $4^{\circ} \mathrm{C}$ R123 control. The solid black line is R123 + diluent control and the solid grey line R123 + barasertib-hQPA (i) and R123 + CSA (ii). B, BODIPY-prazosin accumulation in OCI AML6.2 cells +/$300 \mathrm{nM}$ barasertib-hQPA (i) or $10 \mu \mathrm{M}$ FTC (ii). The dotted lines are the $4^{\circ} \mathrm{C}$ BODIPY control. The solid black line is BODIPY + diluent control and the solid grey line BODIPY + barasertib-hQPA (i) and BODIPY + FTC (ii). Plots are representative of a single experiment which was done in triplicate. C, UIC2 binding in KG-1a cells in the presence of $5 \mu \mathrm{M}$ vinblastine (i), $1 \mu \mathrm{M}$ barasertib-hQPA (ii) or a combination of both (iii). The dark filled line is the diluent control and the light line indicates any shift. D, 300nM $\left[{ }^{14} \mathrm{C}\right]$-barasertibhQPA uptake in Pgp expressing OCI-AML3DNR cells +/- the Pgp modulator CSA and in OCI-AML6.2 cells +/- the BCRP modulator FTC. Pgp/BCRP negative OCl-AML3 cells have been used as a positive control $\left({ }^{*} p=0.004 /{ }^{* *} p=0.005\right.$ ) (analysed using paired samples t-test), $+95 \%$ confidence interval). Diluent controls were included for each modulator. Columns, mean of three experiments; bars, SD.

Pgp negative samples (Figure 5B). BCRP positive primary samples were also significantly $(\mathrm{p}=<0.001)$ less sensitive to barasertib-hQPA induced pHH3 inhibition compared to BCRP negative samples (Figure 5C). However, a sharp distinction between cell lines and primary samples was noted. Whereas the transporter-expressing cell lines were insensitive to down-regulation of $\mathrm{pHH} 3$ at concentrations of up to $1000 \mathrm{nM}$ barasertib-hQPA even after 24 hours, $\mathrm{IC}_{50} \mathrm{pHH} 3$ inhibition was achieved in $94.6 \%$ of primary samples at $300 \mathrm{nM}$ barasertibhQPA for one hour.

\section{Discussion}

The success of agents such as imatinib in the treatment of chronic myelogenous leukaemia has lead to an increase in confidence that small-molecule inhibitors of specific kinases may prove to be highly effective anticancer agents [8]. The aurora kinase family are essential for normal mitotic progression and have attracted great interest as potential new therapeutic targets. Overexpression of aurora kinases have been reported in many tumour types and linked to a poor prognosis. The aurora-B kinase specific inhibitor barasertib-hQPA has shown tumouricidal activity against a panel of tumour cell lines and xenograft models including those of AML origin [22-24,27]. Our group have recently reported that the FLT3-ITD mutation is a secondary target for barasertib-hQPA and that primary AML samples with an ITD mutation in the FLT3 gene are particularly sensitive to the drug [22]. The FLT3 gene is one of the most commonly mutated genes in AML with the FLT3-ITD mutation appearing in roughly $24 \%$ of cases and being associated with a poor prognosis $[46,47]$. Barasertib-hQPA is therefore of potential use as a future treatment in AML.

Intrinsic MDR or treatment-induced MDR has historically been one of the major obstacles to the effective treatment of patients with AML. Elevated expression of the MDR1 gene coding for the drug efflux pump Pgp is one of the best characterized resistance mechanisms in AML with high expression in elderly patients particularly associated with worse complete remission rates [30]. The ABCG2 gene encoding BCRP has also been shown to be overexpressed in AML patients and to significantly affect the duration of complete remission [36]. Any potential new drug for the treatment of AML should therefore be screened for its efficacy in patients expressing high levels of these drug transporters.

Aurora-B is known to phosphorylate Histone H3 $(\mathrm{pHH} 3)$ at the serine 10 position during mitosis $[12,13]$. We have previously demonstrated a method for measuring $\mathrm{pHH} 3$ expression in our cell lines and more importantly in our primary samples and its subsequent downregulation after barasertib-hQPA treatment [22]. We can therefore use pHH3 expression as a biomarker for barasertib-hQPA activity. Initial experiments showed that our Pgp positive (KG-1a) and BCRP positive (OCIAML6.2) cell lines were much less sensitive to barasertib-hQPA in comparison to transporter negative cell lines. This was seen at both the biomarker and 


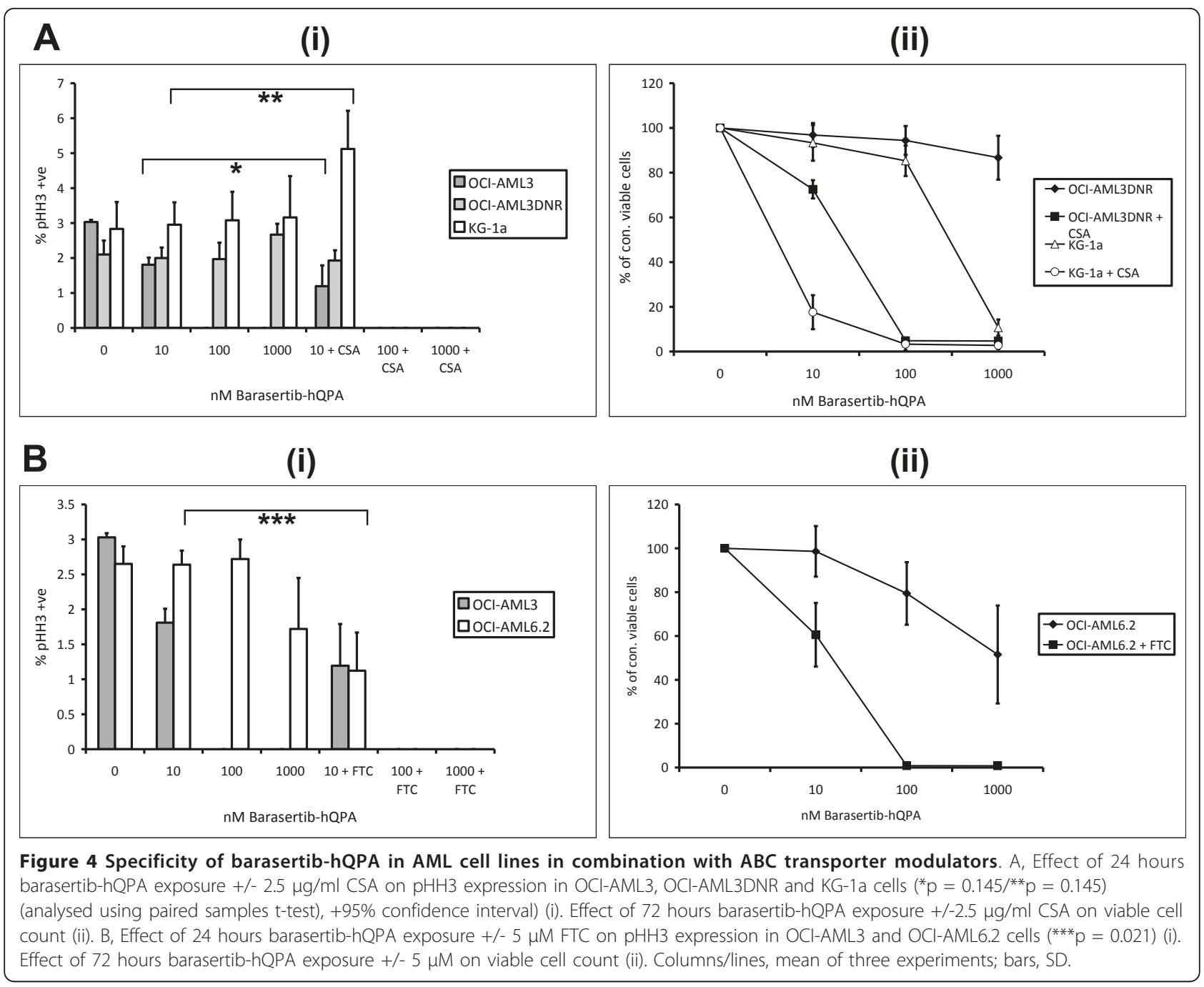

subsequent viability level. Because we had no parental Pgp negative comparison for the KG-1a cell line we wanted to create a Pgp expressing cell line from the OCI-AML3 cells. The subsequently developed Pgp expressing OCI-AML3DNR cell line was more resistant to barasertib-hQPA compared to the sensitive OCIAML3 parent cells (Figure 2B). This resistance to barasertib-hQPA in the transporter positive cell lines was reversed when known inhibitors of Pgp and BCRP were co-cultured with barasertib-hQPA (Figure 4). There was an initial spike in KG-1a pHH3 levels at $10 \mathrm{nM}$ barasertib-hQPA with the addition of CSA (Figure 4A(i)). This spike was also seen in the sensitive U937 cells also at 10 nM barasertib-hQPA (Figure $2 \mathrm{~A}(\mathrm{i})$ ) and to a lesser extent in the OCI-AML3 cells (Figure 2B(i)) indicating that CSA is sensitizing the Pgp expressing KG-1a cells to barasertib-hQPA. By using ${ }^{14}[\mathrm{C}]$-barasertib-hQPA in combination with known Pgp and BCRP inhibitors we show definitively that the drug is being effluxed by these transporters in the OCI-AML3DNR and OCI-AML6.2 cell lines.

Inhibiting Pgp as a way of reversing MDR has been intensively studied for many years. Pharmacological inhibition of Pgp by small-molecule antagonists has been studied in several AML trials with various agents but only yielding little clinical success [48-51]. Many of these agents are substrates for other transporters and enzyme systems resulting in unpredictable pharmacokinetic interactions in the presence of chemotherapy agents. Recently more specific so called third generation inhibitors of MDR have been developed that have the potential to minimize any drug-drug interactions [52]. A combination of these inhibitors with barasertib-hQPA could circumvent any problem of drug efflux by $A B C$ transporters seen with this drug.

We measured pHH3 expression in 37 primary AML samples cultured for one hour with or without barasertib-hQPA. 9/37 (24.3\%) were positive for Pgp and 9/35 

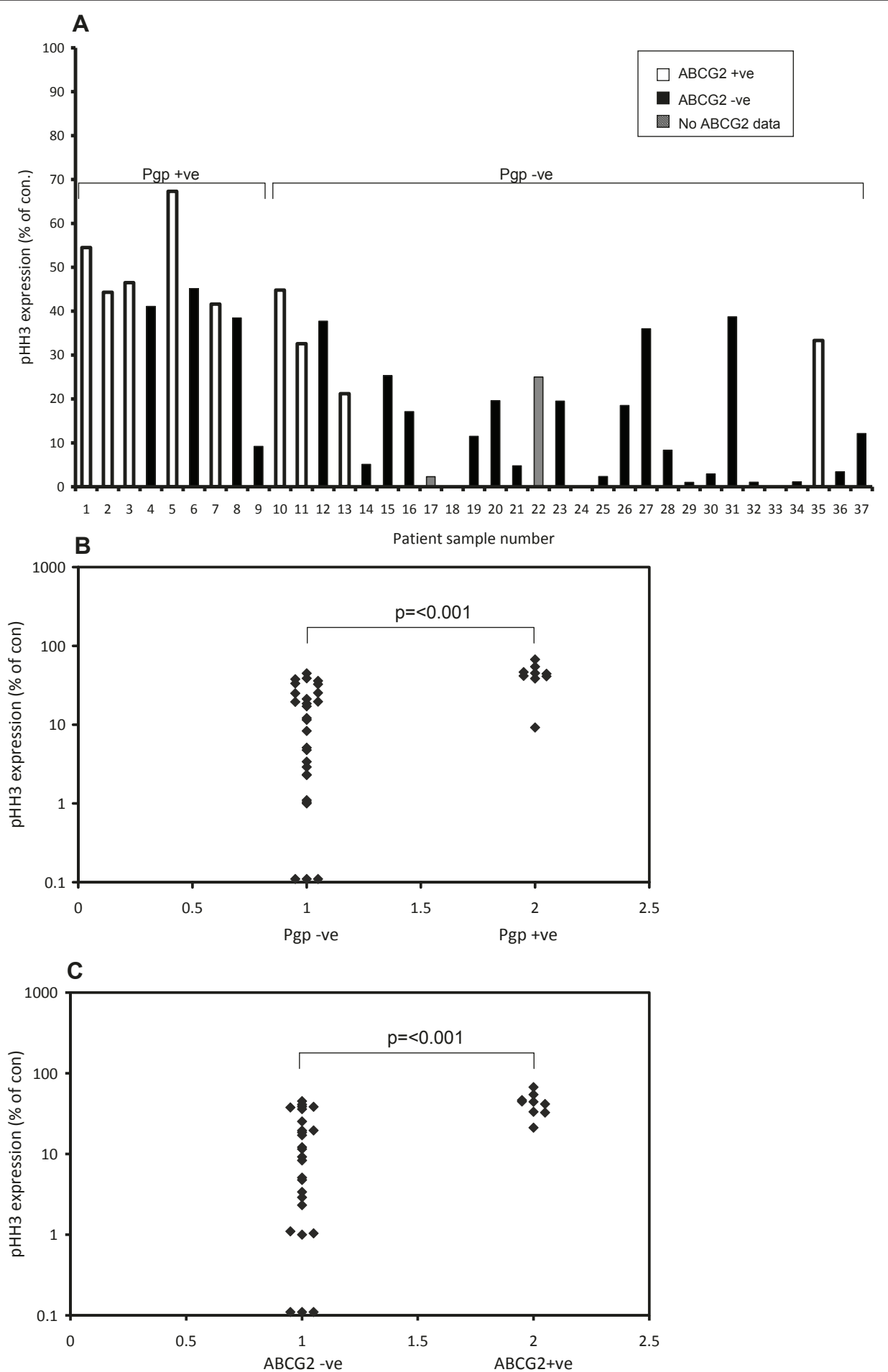

Figure 5 Pgp and BCRP positive primary AML samples are less sensitive to barasertib-hQPA induced pHH3 inhibition. A, Flow cytometric pHH3 expression in 37 primary AML samples pre-incubated with cytokine cocktail for 48 hours and then treated with $300 \mathrm{nM}$ barasertib-hQPA for 60 minutes. Pgp expression was determined by modulation of R123 efflux and MRK-16 expression. ABCG2 message levels were measured using real-time PCR. B, Scatter plot demonstrating that Pgp positive primary samples are less sensitive to barasertib-hQPA induced $\mathrm{pHH} 3$ inhibition than Pgp negative samples $(\mathrm{p}=<0.001)$, Mann-Whitney. C, Scatter plot demonstrating that BCRP positive primary samples are less sensitive to barasertib-hQPA induced pHH3 inhibition than BCRP negative samples $(p=<0.001)$, Mann-Whitney. 
(25.7\%) were positive for BCRP with a significant correlation $(\mathrm{p}=0.008, \mathrm{r} 2=0.238$ ) seen for co-expression. This data agrees with results seen previously [36]. Pgp positive samples were significantly less sensitive to barasertib-hQPA induced $\mathrm{pHH} 3$ inhibition compared to Pgp negative samples $(\mathrm{p}=0.001)$ as were BCRP positive samples compared to BCRP negative samples ( $\mathrm{p}=$ 0.001). Importantly though, $>50 \%$ inhibition of $\mathrm{pHH} 3$ was still seen in all but 2 primary samples (94.6\%). So certainly at the level of the biomarker we see a much better response in $\mathrm{ABC}$ transporter positive primary samples than in transporter positive cell lines at the corresponding dose of barasertib-hQPA. Whereas in the transporter positive cell lines we demonstrated efflux of barasertib-hQPA using radio-labelled drug it is clear that all of our primary samples retained enough drug to target the $\mathrm{pHH} 3$ biomarker. This difference in response may be explained by the 'artificially' high transporter expression seen in the cell lines. For example, if we look at our measure of Pgp function, the mean CSA modulation ratio in our primary samples was 1.74 . Four times this was seen in the Pgp expressing OCI-AML3DNR cell line and greater than seven times seen in the Pgp expressing KG-1a cell line. Likewise the amount of Pgp protein measured using the MRK-16 antibody was two-folds higher in the OCI-AML3DNR cells and seven-folds higher in the KG-1a cells compared to the mean value of 1.13 seen in primary samples.

\section{Conclusions}

MDR AML cell lines are a useful tool to model transporter mediated drug resistance but their efflux activity is extreme compared to that found in primary AML samples. Most clinical trials with Pgp modulators have been unsuccessful and thus the importance of efflux pumps in AML chemoresistance is unclear. Clinical trials with barasertib may help to resolve this issue, since pHH3 is such a clear-cut marker of efficacy at the cellular level. We conclude that Pgp and BCRP expression levels and $\mathrm{pHH} 3$ down-regulation in patients treated with barasertib should be monitored in order to establish whether transporter-mediated efflux is sufficient to adversely impact on the efficacy of the agent.

\section{Methods \\ Materials}

Materials were from Sigma (Poole, Dorset UK) unless otherwise stated. Barasertib-hQPA was provided by AstraZeneca (Cheshire, UK).

\section{Cell lines}

The OCI-AML3 myeloid leukaemia cell line was obtained from the German Collection of Microorganisms and Cell Cultures (DSMZ, Braunschweig, Germany). U937, HL-60 and KG-1a cell lines were from the European Collection of Animal Cell Cultures (Salisbury, UK). The ABCG2 stably transfected OCI-AML6.2 cells were a gift from Dr. Jo Mountford (University of Glasgow, UK). The HL-60ADR [43] cell line was a gift from Mark Center (Kansas State University, USA). U937, OCIAML3 and OCI-AML6.2 cell lines were maintained in RPMI 1640 medium with 10\% foetal calf serum (FCS; First Link, Birmingham, UK), 2 mM L-glutamine, 100 U/ $\mathrm{ml}$ penicillin and $10 \mu \mathrm{g} / \mathrm{ml}$ streptomycin. The KG-1a cell line was maintained as above with $20 \%$ FCS. All cultures were kept at $37^{\circ} \mathrm{C}$ in $5 \% \mathrm{CO}_{2}$ and all experiments were performed with cell lines in log phase. Continued testing to authenticate these cell lines was initially performed using a panel of monoclonal antibodies and later by STR fingerprinting. Mycoplasma testing was carried out routinely using a Mycoalert mycoplasma detection kit (Lonza, Rockland, USA) and following the manufacturer's instructions.

\section{Selection of Daunorubicin resistant OCI-AML3 cells}

OCI-AML3 cells were initially exposed to daunorubicin (DNR) at a concentration of $10 \mathrm{nM}$, which represented the $\mathrm{IC}_{50}$ concentration. Cells were seeded at $5 \times 10^{5} / \mathrm{ml}$ in $50 \mathrm{ml}$ of complete medium containing $10 \mathrm{nM}$ DNR. At days 3, 10 and 14, $50 \mathrm{ml}$ of fresh culture medium without DNR was added. At day 18 cells were pelleted and re-suspended in $160 \mathrm{ml}$ medium containing $10 \mathrm{nM}$ DNR. From day 26 to day 35 the DNR containing medium was changed once per week. At day 35 there were very few remaining viable cells, so cells were separated over Histopaque to exclude dead cells and cell debris. The remaining cells were re-suspended in $10 \mathrm{ml}$ of medium containing $10 \mathrm{nM}$ DNR up until day 45 when cell growth was seen. Cells were maintained at this drug concentration until their growth rate approached that of untreated OCI-AML3 cells. Over the next 10 weeks cells were exposed to gradually increasing concentrations of DNR up to a final concentration of $15 \mathrm{nM}$. By using the R123 accumulation assay these cells were confirmed to have increased levels of Pgp function and were subsequently cloned by limiting dilution. Cells were serially diluted in 96 well plates down to a concentration of 1 cell/well in medium containing $15 \mathrm{nM}$ DNR. Any cells showing outgrowth were then gradually cultured in medium containing $15 \mathrm{nM}$ DNR up to sufficient numbers to be able to assay for Pgp protein and function. One clone showed an increase in both Pgp protein expression and function. This clone was named OCI-AML3DNR and was then cultured under standard conditions with $15 \mathrm{nM}$ DNR and also cryo-preserved for future use. DNR was removed from culture medium 7 days prior to any experimental procedure. 
OCI-AML3/OCI-AML3DNR/OCI-AML6.2 genetic analysis

DNA was prepared using a QIAamp DNA blood mini kit (Qiagen, Crawley, UK) and 5 ng DNA was amplified using the Powerplex 16 System (Promega, Southampton, UK) to assess STR. The products were run on a 3130 Genetic Analyser and the data analysed using GeneMapper ID v3.2 software.

\section{Patient samples}

Presentation blood or bone marrow samples from multiple centres were obtained at diagnosis from patients with AML (excluding M3 subtype) and taken into preservative-free heparin or into EDTA tubes. All samples were pre-treatment and only samples received within 48 hours of being removed from the patient were analyzed. Use of these samples was approved by the Nottingham 1 Research Ethics Committee (reference number 06/ Q2403/16). Mononuclear cells were isolated using a standard density gradient/centrifugation method with Histopaque and cryopreserved in liquid nitrogen. For analysis, cryopreserved samples were thawed and rested in culture medium enriched to 20\% FCS for 90 minutes before experimental procedures. Thawed and rested samples were then subjected to viability analysis using trypan blue exclusion and only samples with $>85 \%$ post-rest viability were used.

\section{Pgp protein expression - MRK-16 mAb}

For Pgp protein expression cells were harvested, washed in PBSAA, and $2 \times 10^{5}$ cells incubated with $1 \mu \mathrm{g}$ MRK-16 anti-Pgp monoclonal antibody (Kamiya Biomedical) or IgG2a isotype control (Dako) for $30 \mathrm{~min}$ at RT. Cells were washed x3 in PBSAA and blocked in $80 \mu \mathrm{l} 20 \%$ normal rabbit serum for $30 \mathrm{~min}$ on ice. $5 \mu \mathrm{l}$ FITC-conjugated goat anti-mouse secondary antibody (Dako) was added and cells incubated for $30 \mathrm{~min}$ on ice. Cells were washed twice in PBSAA and cell line data collected using a FACS calibur. Patient samples had the added step of the addition of $5 \mu \mathrm{l} \mathrm{CD45PerCP}$ (Becton Dickinson, UK) and $5 \mu \mathrm{l}$ Normal Mouse serum before being washed twice in PBSAA and collected using a FACS calibur. Labelling the patient samples with CD45PerCP allowed the leukemic (CD45 low/ side scatter low) cells to be gated [53].

\section{Determination of Pgp, BCRP and MRP function}

Functional Pgp expression was determined by modulation of R123 efflux. Cells were resuspended at $1 \times 10^{6} /$ $\mathrm{ml}$ in culture medium and incubated $\left(75\right.$ minutes, $\left.37^{\circ} \mathrm{C}\right)$ with R123 $(200 \mathrm{ng} / \mathrm{ml})$ with or without $2.5 \mu \mathrm{g} / \mathrm{ml} \mathrm{CSA}$ (supplied by the pharmacy of Nottingham City Hospital) or diluent control. Control tubes containing R123 were placed on ice to halt the reaction [53,54]. Functional BCRP expression was measured similarly and was determined by modulation of BODIPY (Invitrogen) efflux.
Cells were resuspended at $1 \times 10^{6} / \mathrm{ml}$ in culture medium and incubated $\left(75\right.$ minutes, $\left.37^{\circ} \mathrm{c}\right)$ with BODIPY ( 25 $\mathrm{nM}$ ) with or without $10 \mu \mathrm{M}$ FTC (Calbiochem) or diluent control. Control tubes containing BODIPY were placed on ice. MRP function was determined by modulation of Calcein-AM (Invitrogen) efflux [55]. Cells were resuspended at $1 \times 10^{6} / \mathrm{ml}$ in culture medium and incubated $\left(75\right.$ minutes, $\left.37^{\circ} \mathrm{C}\right)$ with Calcein-AM $(0.1 \mu \mathrm{M})$ with or without $40 \mu \mathrm{M}$ MK-571 (Enzo life sciences, UK) or diluent control. Control tubes containing Calcein-AM were placed on ice. All tests were carried out in duplicate. Cells were washed twice in PBSAA at $4^{\circ} \mathrm{c}$, collected using a FACS calibur (Becton Dickinson) and analysed using Cellquest software. Mean fluorescence intensity (MFI) of each sample in the FL1 channel was measured, since this corresponds to R123/BODIPY retention. The geometric mean fluorescence modulation ratio is calculated as: (MFI with modulator - cold control MFI)/(MFI with diluent control - cold control MFI) $[53,54]$.

\section{Real-time PCR for ABCG2 message levels}

Thawed and rested AML blasts were depleted of CD2 ${ }^{+}$ cells using Dynabeads (to deplete NK and T cells some of which express ABCG2 mRNA [56]. RNA from CD2 depleted AML blasts and the ABCG2 positive OCIAML6.2 cell line was prepared using QIAamp RNA kits with DNase treatment according to the manufacturer's instructions (Qiagen). Quantitative PCR was carried out as previously reported [22]. The relative expression levels of ABCG2 transcripts were calculated as the ratio between the level of ABCG2 and the level of $\beta 2 \mathrm{M}$. Both sets of real time primers used have previously been published $[57,58]$.

\section{Determination of cell viability}

This was done by a previously published in-house method which makes use of an internal standard and allows rapid enumeration of viable cells by flow cytometric counting of cells labelled with 7-amino Actinomycin D (7-AAD) [59].

\section{Histone $\mathrm{H} 3$ phosphorylation status}

This was done by flow cytometry using anti-phosphohistone H3 (Ser 10) mouse monoclonal antibody (Upstate; now part of Millipore, Livingstone, UK) as previously described [22]. 37 primary AML samples were cultured at $10^{6} / \mathrm{ml}$ in RPMI 1640 with $10 \%$ FCS, $2 \mathrm{mM}$ L-glutamine, supplemented with $20 \mathrm{ng} / \mathrm{ml}$ interleukin (IL) $-3,20 \mathrm{ng} / \mathrm{ml}$ stem cell factor, $20 \mathrm{ng} / \mathrm{ml} \mathrm{IL-6} \mathrm{+}$ $25 \mathrm{ng} / \mathrm{ml}$ granulocyte colony-stimulating factor $(\mathrm{R}+\mathrm{D}$ Systems) $+0.07 \mu \mathrm{l} / \mathrm{ml}$ beta-mercaptoethanol for 48 hours. Samples were then treated with $300 \mathrm{nM}$ barasertib-hQPA for 60 minutes followed by pHH3 measurement by flow cytometry. $\mathrm{pHH} 3$ expression was calculated as a percentage of untreated controls. 


\section{UIC2 shift assay}

The reactivity of the UIC2 antibody with Pgp is increased by the addition of Pgp transported compounds and has been described by Park [44]. Briefly, cells were resuspended at $5 \times 10^{5} / \mathrm{ml}$ in culture medium and incubated for 10 minutes at $37^{\circ} \mathrm{C}, 5 \% \mathrm{CO}_{2} .1 \mu \mathrm{M}$ barasertibhQPA or $5 \mu \mathrm{M}$ of the known Pgp substrate vinblastine, or both was added to cells in duplicate and incubated at $37^{\circ} \mathrm{C}, 5 \% \mathrm{CO}_{2}$ for 4 hours. Either $0.1 \mu \mathrm{g} / \mathrm{ml} \mathrm{UIC} 2$ monoclonal antibody (Immunotech) or IgG2a isotype control (Dako) was added to paired samples and incubated for a further 15 minutes. Cells were washed twice in PBSAA, resuspended in $20 \%$ Rabbit serum, and placed on ice for 30 minutes. $5 \mu$ FITC-conjugated rabbit anti-mouse secondary antibody (Dako) was then added to cells, and following 30 minutes incubation on ice, cells were washed twice and analysed by flow cytometry. An increase in FL1 fluorescence compared to a paired control is taken to indicate the presence of a Pgp substrate.

\section{Radio-labelled drug accumulation assay}

Pgp expressing OCI-AML3DNR cells and the Pgp null OCI-AML3 parent cell line were plated in duplicate onto 12 well plates and pre-incubated for 30 mins with or without the Pgp modulator CSA at $2.5 \mu \mathrm{g} / \mathrm{ml}$. The BRCP expressing OCI-AML6.2 cells were treated similarly using BCRP null OCI-AML3 cells as a control and $10 \mu \mathrm{M}$ FTC as the BCRP modulator. Medium containing $0.017 \mu \mathrm{Ci}$ radio-labelled $\left[{ }^{14} \mathrm{C}\right]$-barasertib-hQPA (AstraZeneca, Cheshire, UK) was then added to give a final drug concentration of $300 \mathrm{nM}$. The cultures were incubated for $1 \mathrm{Hr}$ at $37^{\circ} \mathrm{C}$ with agitation after 30 mins. The radioactive medium was then aspirated and cells washed twice with ice cold PBS before permeabilisation with $1 \%$ sodium dodecylsulphate (Sigma). Cell extracts were then added to scintillation fluid (Perkin Elmer) and radioactive drug retention measured using a TRI-CARB 2100TR liquid scintillation analyser (Packard).

\section{Statistical Analysis}

Statistical analysis was carried out using the Statistical Package for Social Sciences, version 16 (SPSS, Chicago, IL, USA). P values of less than or equal to 0.05 were considered to represent significance.

\footnotetext{
Acknowledgements

We thank Drs E Anderson and R Wilkinson at AstraZeneca UK Ltd for the provision of barasertib-hQPA, a contribution towards reagent costs and useful discussions. We acknowledge the Nottingham 1 Research Ethics Committee (reference number 06/Q2403/16) for permitting access to stored samples from AML patients. We thank lan Carter and Alun McCarthy for running the Powerplex reactions.
}

\footnotetext{
Author details

'Department of Academic Haematology, The University of Nottingham, Clinical Sciences Building, Hucknall Road, Nottingham, NG5 1PB, UK.
}

²Department of Academic Haematology, Nottingham University Hospitals (City Campus), Clinical Sciences Building, Hucknall Road, Nottingham, NG5 1PB, UK. ${ }^{3}$ Centre for Clinical Haematology, Nottingham University Hospital (City Campus), Hucknall Road, Nottingham, NG5 1PB, UK.

\section{Authors' contributions}

MG carried out all cell line and primary sample experiments and drafted the manuscript. MG and CS performed the RT PCR for ABCG2 message levels. CS performed the cell line genetic analysis. MP and NR conceived of the study. MP participated in the design and coordination of the study and helped to draft the manuscript. All authors critically read the manuscript and approved the final version.

\section{Competing interests}

The authors declare that they have no competing interests.

Received: 1 March 2011 Accepted: 16 June 2011

Published: 16 June 2011

\section{References}

1. Andrews PD, Knatko E, Moore WJ, Swedlow JR: Mitotic mechanics: the auroras come into view. Curr Opin Cell Biol 2003, 15:672-683.

2. Chieffi $P$, Cozzolino L, Kisslinger A, Libertini S, Staibano S, Mansueto G, De Rosa G, Villacci A, Vitale M, Linardopoulos S, et al: Aurora B expression directly correlates with prostate cancer malignancy and influence prostate cell proliferation. Prostate 2006, 66:326-333.

3. Han H, Bearss DJ, Browne LW, Calaluce R, Nagle RB, Von Hoff DD: Identification of differentially expressed genes in pancreatic cancer cells using cDNA microarray. Cancer Res 2002, 62:2890-2896.

4. Katayama H, Ota T, Jisaki F, Ueda Y, Tanaka T, Odashima S, Suzuki F, Terada Y, Tatsuka M: Mitotic kinase expression and colorectal cancer progression. J Natl Cancer Inst 1999, 91:1160-1162.

5. Tong $T$, Zhong $Y$, Kong J, Dong L, Song Y, Fu M, Liu Z, Wang M, Guo L, Lu S, et al: Overexpression of Aurora-A contributes to malignant development of human esophageal squamous cell carcinoma. Clin Cancer Res 2004, 10:7304-7310.

6. Ikezoe T, Yang J, Nishioka C, Tasaka T, Taniguchi A, Kuwayama Y, Komatsu N, Bandobashi K, Togitani K, Koeffler HP, Taguchi H: A novel treatment strategy targeting Aurora kinases in acute myelogenous leukemia. Mol Cancer Ther 2007, 6:1851-1857.

7. Yang J, Ikezoe T, Nishioka C, Tasaka T, Taniguchi A, Kuwayama Y, Komatsu N, Bandobashi K, Togitani K, Koeffler HP, et al: AZD1152, a novel and selective aurora B kinase inhibitor, induces growth arrest, apoptosis, and sensitization for tubulin depolymerizing agent or topoisomerase II inhibitor in human acute leukemia cells in vitro and in vivo. Blood 2007.

8. Crossman LC, O'Brien S: Clinical results with imatinib in chronic myeloid leukaemia. Leuk Res 2004, 28(Suppl 1):S3-9.

9. Carmena M, Earnshaw WC: The cellular geography of aurora kinases. Nature Reviews Molecular Cell Biology 2003, 4:842-854.

10. Fu J, Bian M, Jiang Q, Zhang C: Roles of Aurora kinases in mitosis and tumorigenesis. Mol Cancer Res 2007, 5:1-10.

11. Vader G, Medema RH, Lens SM: The chromosomal passenger complex: guiding Aurora-B through mitosis. J Cell Biol 2006, 173:833-837.

12. Bhaumik SR, Smith $E$, Shilatifard A: Covalent modifications of histones during development and disease pathogenesis. Nat Struct Mol Biol 2007, 14:1008-1016.

13. Giet $R$, Glover DM: Drosophila aurora $B$ kinase is required for histone $H 3$ phosphorylation and condensin recruitment during chromosome condensation and to organize the central spindle during cytokinesis. J Cell Biol 2001, 152:669-682.

14. Van Hooser A, Goodrich DW, Allis CD, Brinkley BR, Mancini MA: Histone H3 phosphorylation is required for the initiation, but not maintenance, of mammalian chromosome condensation. J Cell Sci 1998, 111(Pt 23):3497-3506.

15. Tang CJ, Lin CY, Tang TK: Dynamic localization and functional implications of Aurora-C kinase during male mouse meiosis. Dev Biol 2006, 290:398-410.

16. Sasai K, Katayama H, Stenoien DL, Fujii S, Honda R, Kimura M, Okano Y, Tatsuka M, Suzuki F, Nigg EA, et al: Aurora-C kinase is a novel chromosomal passenger protein that can complement Aurora-B kinase function in mitotic cells. Cell Motil Cytoskeleton 2004, 59:249-263. 
17. Yan X, Cao L, Li Q, Wu Y, Zhang H, Saiyin H, Liu X, Zhang X, Shi Q, Yu L: Aurora $C$ is directly associated with Survivin and required for cytokinesis. Genes Cells 2005, 10:617-626.

18. Ditchfield C, Johnson VL, Tighe A, Ellston R, Haworth C, Johnson T, Mortlock A, Keen N, Taylor SS: Aurora B couples chromosome alignment with anaphase by targeting BubR1, Mad2, and Cenp-E to kinetochores. Journal of Cell Biology 2003, 161:267-280.

19. Harrington EA, Bebbington D, Moore J, Rasmussen RK, Ajose-Adeogun AO, Nakayama T, Graham JA, Demur C, Hercend T, Diu-Hercend A, et al: VX680 , a potent and selective small-molecule inhibitor of the Aurora kinases, suppresses tumor growth in vivo. Nature Medicine 2004, 10:262-267.

20. Hauf S, Cole RW, LaTerra S, Zimmer C, Schnapp G, Walter R, Heckel A, van Meel J, Rieder CL, Peters JM: The small molecule Hesperadin reveals a role for Aurora B in correcting kinetochore-microtubule attachment and in maintaining the spindle assembly checkpoint. Journal of Cell Biology 2003, 161:281-294.

21. Keen N, Taylor S: Aurora-kinase inhibitors as anticancer agents. Nature Reviews Cancer 2004, 4:927-936.

22. Grundy M, Seedhouse C, Shang S, Richardson J, Russell N, Pallis M: The FLT3 internal tandem duplication mutation is a secondary target of the aurora B kinase inhibitor AZD1152-HQPA in acute myelogenous leukemia cells. Mol Cancer Ther 9:661-672.

23. Wilkinson RW, Odedra R, Heaton SP, Wedge SR, Keen NJ, Crafter C, Foster JR, Brady MC, Bigley A, Brown E, et al: AZD1152, a selective inhibitor of Aurora B kinase, inhibits human tumor xenograft growth by inducing apoptosis. Clin Cancer Res 2007, 13:3682-3688.

24. Mortlock AA, Foote KM, Heron NM, Jung FH, Pasquet G, Lohmann JJ, Warin N, Renaud F, De Savi C, Roberts NJ, et al: Discovery, synthesis, and in vivo activity of a new class of pyrazoloquinazolines as selective inhibitors of aurora B kinase. J Med Chem 2007, 50:2213-2224.

25. Joel SP, Oke A, Foot N, Keen N, Bonnet D, Lister TA, Fitzgibbon J: The activity of the novel aurora kinase B inhibitor AZD1152 in acute myeloid leukaemia cells. Blood 2005, 106:943A-943A.

26. Oke A, Pearce D, Wilkinson RW, Crafter C, Odedra R, Cavenagh J, Fitzgibbon J, Lister AT, Joel S, Bonnet D: AZD1152 Rapidly and Negatively Affects the Growth and Survival of Human Acute Myeloid Leukemia Cells In vitro and In vivo. Cancer Res 2009.

27. Walsby E, Walsh V, Pepper C, Burnett A, Mills K: Effects of the aurora kinase inhibitors AZD1152-HQPA and ZM447439 on growth arrest and polyploidy in acute myeloid leukemia cell lines and primary blasts. Haematologica 2008

28. Stone RM, O'Donnell MR, Sekeres MA: Acute myeloid leukemia. Hematology Am Soc Hematol Educ Program 2004, 98-117.

29. Lowenberg B, Griffin JD, Tallman MS: Acute myeloid leukemia and acute promyelocytic leukemia. Hematology Am Soc Hematol Educ Program 2003, 82-101.

30. Leith CP, Kopecky KJ, Godwin J, McConnell T, Slovak ML, Chen IM, Head DR, Appelbaum FR, Willman CL: Acute myeloid leukemia in the elderly: assessment of multidrug resistance (MDR1) and cytogenetics distinguishes biologic subgroups with remarkably distinct responses to standard chemotherapy. A Southwest Oncology Group study. Blood 1997, 89:3323-3329.

31. Appelbaum FR, Rowe JM, Radich J, Dick JE: Acute myeloid leukemia. Hematology Am Soc Hematol Educ Program 2001, 62-86.

32. Gottesman MM, Fojo T, Bates SE: Multidrug resistance in cancer: role of ATP-dependent transporters. Nat Rev Cancer 2002, 2:48-58.

33. Schinkel AH, Jonker JW: Mammalian drug efflux transporters of the ATP binding cassette (ABC) family: an overview. Adv Drug Deliv Rev 2003, 55:3-29.

34. de Jonge-Peeters SD, Kuipers F, de Vries EG, Vellenga $E$ : $A B C$ transporter expression in hematopoietic stem cells and the role in $A M L$ drug resistance. Crit Rev Oncol Hematol 2007, 62:214-226.

35. Leith CP, Kopecky KJ, Chen IM, Eijdems L, Slovak ML, McConnell TS, Head DR, Weick J, Grever MR, Appelbaum FR, Willman CL: Frequency and clinical significance of the expression of the multidrug resistance proteins MDR1/P-glycoprotein, MRP1, and LRP in acute myeloid leukemia. A Southwest Oncology Group Study. Blood 1999, 94:1086-1099.

36. Damiani D, Tiribelli M, Calistri E, Geromin A, Chiarvesio A, Michelutti A, Cavallin M, Fanin R: The prognostic value of P-glycoprotein $(A B C B)$ and breast cancer resistance protein (ABCG2) in adults with de novo acute myeloid leukemia with normal karyotype. Haematologica 2006, 91:825-828.

37. Benderra Z, Faussat AM, Sayada L, Perrot JY, Chaoui D, Marie JP, Legrand O: Breast cancer resistance protein and P-glycoprotein in 149 adult acute myeloid leukemias. Clin Cancer Res 2004, 10:7896-7902.

38. van der Pol MA, Broxterman HJ, Pater JM, Feller N, van der Maas M, Weijers GW, Scheffer GL, Allen JD, Scheper RJ, van Loevezijn A, et al: Function of the $A B C$ transporters, $\mathrm{P}$-glycoprotein, multidrug resistance protein and breast cancer resistance protein, in minimal residual disease in acute myeloid leukemia. Haematologica 2003, 88:134-147.

39. Guo J, Anderson MG, Tapang P, Palma JP, Rodriguez LE, Niquette A, Li J, Bouska JJ, Wang G, Semizarov D, et al: Identification of genes that confer tumor cell resistance to the Aurora B kinase inhibitor, AZD1152. Pharmacogenomics J 2009, 9:90-102.

40. Cumber PM, Jacobs A, Hoy T, Whittaker JA, Tsuruo T, Padua RA: Increased drug accumulation ex vivo with cyclosporin in chronic lymphatic leukemia and its relationship to epitope masking of P-glycoprotein Leukemia 1991, 5:1050-1053.

41. Rabindran SK, Ross DD, Doyle LA, Yang W, Greenberger LM: Fumitremorgin $C$ reverses multidrug resistance in cells transfected with the breast cancer resistance protein. Cancer Res 2000, 60:47-50.

42. Gekeler V, Ise W, Sanders KH, Ulrich WR, Beck J: The leukotriene LTD4 receptor antagonist MK571 specifically modulates MRP associated multidrug resistance. Biochem Biophys Res Commun 1995, 208:345-352.

43. Krishnamachary N, Ma L, Zheng L, Safa AR, Center MS: Analysis of MRP gene expression and function in HL60 cells isolated for resistance to adriamycin. Oncol Res 1994, 6:119-127.

44. Park SW, Lomri N, Simeoni LA, Fruehauf JP, Mechetner E: Analysis of P-glycoprotein-mediated membrane transport in human peripheral blood lymphocytes using the UIC2 shift assay. Cytometry A 2003, 53:67-78.

45. Mechetner EB, Schott B, Morse BS, Stein WD, Druley T, Davis KA, Tsuruo T, Roninson IB: P-glycoprotein function involves conformational transitions detectable by differential immunoreactivity. Proc Natl Acad Sci USA 1997 94:12908-12913.

46. Gilliland DG, Griffin JD: The roles of FLT3 in hematopoiesis and leukemia. Blood 2002, 100:1532-1542.

47. Hunter HM, Pallis M, Seedhouse CH, Grundy M, Gray C, Russell NH: The expression of P-glycoprotein in AML cells with FLT3 internal tandem duplications is associated with reduced apoptosis in response to FLT3 inhibitors. British Journal of Haematology 2004, 127:26-33.

48. Baer MR, George SL, Dodge RK, O'Loughlin KL, Minderman H, Caligiuri MA, Anastasi J, Powell BL, Kolitz JE, Schiffer CA, et al: Phase 3 study of the multidrug resistance modulator PSC-833 in previously untreated patients 60 years of age and older with acute myeloid leukemia: Cancer and Leukemia Group B Study 9720. Blood 2002, 100:1224-1232.

49. Greenberg $P L$, Lee SJ, Advani R, Tallman MS, Sikic Bl, Letendre L, Dugan K, Lum B, Chin DL, Dewald G, et al: Mitoxantrone, etoposide, and cytarabine with or without valspodar in patients with relapsed or refractory acute myeloid leukemia and high-risk myelodysplastic syndrome: a phase III trial (E2995). J Clin Oncol 2004, 22:1078-1086.

50. List AF, Kopecky KJ, Willman CL, Head DR, Persons DL, Slovak ML, Dorr R, Karanes $\mathrm{C}$, Hynes HE, Doroshow JH, et al: Benefit of cyclosporine modulation of drug resistance in patients with poor-risk acute myeloid leukemia: a Southwest Oncology Group study. Blood 2001, 98:3212-3220.

51. van der Holt B, Lowenberg B, Burnett AK, Knauf WU, Shepherd J, Piccaluga PP, Ossenkoppele GJ, Verhoef GE, Ferrant A, Crump M, et al: The value of the MDR1 reversal agent PSC-833 in addition to daunorubicin and cytarabine in the treatment of elderly patients with previously untreated acute myeloid leukemia (AML), in relation to MDR1 status at diagnosis. Blood 2005, 106:2646-2654.

52. Lancet JE, Baer MR, Duran GE, List AF, Fielding R, Marcelletti JF, Multani PS, Sikic Bl: A phase I trial of continuous infusion of the multidrug resistance inhibitor zosuquidar with daunorubicin and cytarabine in acute myeloid leukemia. Leuk Res 2009, 33:1055-1061.

53. Pallis M, Das-Gupta E: Flow cytometric measurement of functional and phenotypic P-glycoprotein. Methods Mol Med 2005, 111:167-181.

54. Pallis M, Fisher J, Truran L, Grundy M, Russell N, Burnett A: Reproducible measurements of AML blast p-glycoprotein function in 2 center analyses. Blood 2005, 105:1367-1368. 
55. Olson DP, Taylor BJ, Ivy SP: Detection of MRP functional activity: calcein AM but not BCECF AM as a Multidrug Resistance-related Protein (MRP1) substrate. Cytometry 2001, 46:105-113.

56. Scharenberg CW, Harkey MA, Torok-Storb B: The ABCG2 transporter is an efficient Hoechst 33342 efflux pump and is preferentially expressed by immature human hematopoietic progenitors. Blood 2002, 99:507-512.

57. Abbott BL, Colapietro AM, Barnes Y, Marini F, Andreeff M, Sorrentino BP: Low levels of ABCG2 expression in adult AML blast samples. Blood 2002, 100:4594-4601.

58. Pallisgaard N, Clausen N, Schroder H, Hokland P: Rapid and sensitive minimal residual disease detection in acute leukemia by quantitative real-time RT-PCR exemplified by $\mathrm{t}(12 ; 21)$ TEL-AML1 fusion transcript. Genes Chromosomes Cancer 1999, 26:355-365.

59. Pallis M, Syan J, Russell NH: Flow cytometric chemosensitivity analysis of blasts from patients with acute myeloblastic leukemia and myelodysplastic syndromes: the use of 7AAD with antibodies to CD45 or CD34. Cytometry 1999, 37:308-313.

\section{Pre-publication history}

The pre-publication history for this paper can be accessed here: http://www.biomedcentral.com/1471-2407/11/254/prepub

doi:10.1186/1471-2407-11-254

Cite this article as: Grundy et al:: P-glycoprotein and breast cancer resistance protein in acute myeloid leukaemia cells treated with the Aurora-B Kinase Inhibitor barasertib-hQPA. BMC Cancer 2011 11:254.

\section{Submit your next manuscript to BioMed Central} and take full advantage of:

- Convenient online submission

- Thorough peer review

- No space constraints or color figure charges

- Immediate publication on acceptance

- Inclusion in PubMed, CAS, Scopus and Google Scholar

- Research which is freely available for redistribution

Submit your manuscript at www.biomedcentral.com/submit
C Biomed Central 